\title{
Powder mixture for the production of microporous ceramics based on hydroxyapatite
}

\author{
Tatiana Safronova ${ }^{1,2, *}$, Stepan Chichulin ${ }^{1}$, Tatiana Shatalova, ${ }^{1,2}$, Yaroslav Filippov ${ }^{2,3}$ \\ 1 Department of Chemistry, Lomonosov Moscow State University, Building, 3, Leninskie Gory, 1, 119991 \\ Moscow, Russia; chichulinsn@gmail.com \\ 2 Department of Materials Science, Lomonosov Moscow State University, Building, 73, Leninskie Gory, 1, \\ 119991 Moscow, Russia; shatalovatb@gmail.com \\ 3 Research Institute of Mechanics, Lomonosov Moscow State University, Michurinsky pr., 1, 119192 Moscow, \\ Russia; \\ * Correspondence: t3470641@yandex.ru ; Tel.: (+79163470641)
}

\begin{abstract}
Powder mixture with given molar ratio $\mathrm{Ca} / \mathrm{P}=1.67$ consisting of brushite (calcium hydrophosphate dihydrate) $\mathrm{CaHPO}_{4} \cdot 2 \mathrm{H}_{2} \mathrm{O}$, calcium oxalate monohydrate $\mathrm{CaC}_{2} \mathrm{O}_{4} \cdot \mathrm{H}_{2} \mathrm{O}$ in form of whewellite and weddellite and some quantity of quasi-amorphous phase was obtained as a result of the interaction of hydroxyapatite powder $\mathrm{Ca}_{10}\left(\mathrm{PO}_{4}\right)_{6}(\mathrm{OH})_{2}$ with an aqueous solution of oxalic acid $\mathrm{H}_{2} \mathrm{C}_{2} \mathrm{O}_{4}$ at a molar ratio of $\mathrm{Ca} 10\left(\mathrm{PO}_{4}\right)_{6}(\mathrm{OH})_{2} / \mathrm{H}_{2} \mathrm{C}_{2} \mathrm{O}_{4}=1: 4$ under mechanical activation conditions. This powder mixture was used to produce microporous monophase ceramics based on hydroxyapatite $\mathrm{Ca} 10\left(\mathrm{PO}_{4}\right)_{6}(\mathrm{OH})_{2}$ with aperient density of $1.25 \mathrm{~g} / \mathrm{cm}^{3}$ after firing at $1200{ }^{\circ} \mathrm{C}$. Microporosity of sintered ceramics was formed due to presence of particles with plate-like morphology, restraining shrinkage during sintering. Microporous ceramics based on hydroxyapatite Ca10 $\left(\mathrm{PO}_{4}\right)_{6}(\mathrm{OH})_{2}$ with roughness of the surface as a consequence of the created microporosity can be recommended as a biocompatible material for the bone defects treatment and as a substrate for bone cell cultivation.
\end{abstract}

Keywords: hydroxyapatite; oxalic acid; powder, whewellite, weddellite, calcium oxalate monohydrate, brushite, calcium hydrophosphate dihydrate, heterophase reaction, ceramics, microporosity

\section{Introduction}

The creation of ceramic materials based on calcium phosphates is one of the intensively developing areas of modern materials science for medicine [1]. These materials are biocompatible and can be used in medicine as a porous matrices for replacing lost or damaged bone tissue or as substrates for cell cultivation. Ceramics based on hydroxyapatite $\mathrm{Ca}_{10}\left(\mathrm{PO}_{4}\right)_{6}(\mathrm{OH})_{2}(\mathrm{HA})$ are widely used as material for bone implants creation due to its stability and the similarity of chemical and phase compositions of inorganic part of natural bone $[2,3]$.

Ceramics for bone implants have to be porous with at least two levels of porosity to mimicking the natural bone. Macro pores have to be not less than $100 \mu \mathrm{m}$ and the dimension of micro pores should be about $10 \mu \mathrm{m}\left[{ }^{4}, 5\right]$.

Microporosity of ceramics giving roughness to the surface can improve biointegration and osteoconductivity of material and ensure effective fixation and reproduction of bone tissue cells, as well as fusion of the implant with the body [ $\left.{ }^{6}\right]$.

Ceramics based on hydroxyapatite are very often prepared from HA powder previously synthesized by various methods. The simplest and most common way to obtain hydroxyapatite powder is its precipitation from an aqueous solution of the corresponding substances, which are phosphoric acid or soluble phosphates of ammonium, sodium, potassium as phosphate ion sources and, soluble calcium salts (acetate, nitrate, chloride) as calcium ion sources $[7,8]$. Another way to prepare HA powders or ceramics consisted in heat treatment of preliminarily homogenized powder mixtures of different salts with the preset molar ratio of $\mathrm{Ca} / \mathrm{P}=1.67\left[^{9}\right]$. 
To create microporosity one can use special thermal treatment scheduler to get undersintered ceramic material [ $\left.{ }^{10}\right]$ or specially via sol-gel synthesis prepared powder system [11]. Another method of microporosity creation consists in using organic [12, $\left.{ }^{13}\right]$ or inorganic $[14,15]$ additives in form of particles with a small dimensions as a sacrificed porogens. Special additives which have ability to decompose with the release of a sufficiently large volumes of gases at different stages of ceramics production can be used to generate microporosity. $\mathrm{CO}_{2}, \mathrm{NH}_{3}$ from $\mathrm{NH}_{4} \mathrm{CO}_{3}$ can be used for example at the stage of slurry preparation [16] or $\mathrm{CO}_{2}$ from sodium of potassium carbonates in presence of melt can be used at the stage of heat treatment [17] for creation of microporosity of material.

In the present work for preparing of microporous HA-ceramics we used intentionally prepared powder mixture including particles with the plate-like morphology expecting that particles with this form would restrain sintering.

The purpose of this work consisted in preparing and investigation of powder mixture with preset molar ratio $\mathrm{Ca} / \mathrm{P}=1,67$ including plate-like particles which able to restrain shrinkage during sintering of HA-ceramics for microporosity creation. To prepare powder mixture with preset molar ratio $\mathrm{Ca} / \mathrm{P}=1,67$ powder of $\mathrm{HA}$ was treated in water solution of oxalic acid $\mathrm{H}_{2} \mathrm{C}_{2} \mathrm{O}_{4}$ under mechanical activation conditions. We expected that interaction of basic calcium phosphate salt $\left(\mathrm{Ca}_{10}\left(\mathrm{PO}_{4}\right)_{6}(\mathrm{OH})_{2}, \mathrm{HA}\right)$ with water solution of oxalic acid $\mathrm{H}_{2} \mathrm{C}_{2} \mathrm{O}_{4}$ give us opportunity to prepare powder mixture including brushite (calcium hydrophosphate dihydrate) $\mathrm{CaHPO}_{4} \cdot 2 \mathrm{H}_{2} \mathrm{O}$ and calcium oxalate monohydrate $\mathrm{CaC}_{2} \mathrm{O}_{4} \cdot \mathrm{H}_{2} \mathrm{O}$.

\section{Materials and Methods}

To obtain powder mixture including calcium hydrophosphate dihydrate (brushite) $\mathrm{CaHPO}_{4} \cdot 2 \mathrm{H}_{2} \mathrm{O}$ and calcium oxalate monohydrate $\mathrm{CaC}_{2} \mathrm{O} 4 \cdot \mathrm{H}_{2} \mathrm{O}$, powders of $\mathrm{HA}$ $\mathrm{Ca}_{10}\left(\mathrm{PO}_{4}\right)_{6}(\mathrm{OH})_{2}$ (CAS No. 1306-06-5, puriss. p.a. $\geq 90 \%$, RiedeldeHaen, Sigma-Aldrich Laborchemikalien, 04238, lot 70080, Germany) and oxalic acid dihydrate $\mathrm{H}_{2} \mathrm{C}_{2} \mathrm{O}_{4} \cdot 2 \mathrm{H}_{2} \mathrm{O}$ (grade "pure", GOST 22180-76) were used. These powders were taken in a molar ratio of $\mathrm{Ca}_{10}\left(\mathrm{PO}_{4}\right)_{6}(\mathrm{OH})_{2} / \mathrm{H}_{2} \mathrm{C}_{2} \mathrm{O}_{4}=1: 4$. The following reaction (1) were used for calculation of quantity of starting powders:

$$
\mathrm{Ca}_{10}\left(\mathrm{PO}_{4}\right)_{6}(\mathrm{OH})_{2}+4 \mathrm{H}_{2} \mathrm{C}_{2} \mathrm{O}_{4} \cdot 2 \mathrm{H}_{2} \mathrm{O}+6 \mathrm{H}_{2} \mathrm{O}=4 \mathrm{CaC}_{2} \mathrm{O}_{4} \cdot \mathrm{H}_{2} \mathrm{O}+6 \mathrm{CaHPO}_{4} \cdot 2 \mathrm{H}_{2} \mathrm{O}
$$

$5.02 \mathrm{~g}$ of oxalic acid dihydrate $\mathrm{H}_{2} \mathrm{C}_{2} \mathrm{O}_{4} \cdot 2 \mathrm{H}_{2} \mathrm{O}$ powder, $10.00 \mathrm{~g}$ of HA Ca10 $\left(\mathrm{PO}_{4}\right)_{6}(\mathrm{OH})_{2}$ powder and $55 \mathrm{~g}$ of grinding media (balls based on $\mathrm{ZrO}_{2}$-ceramics) were places in agate vessel. $40 \mathrm{ml}$ of distilled water was added to the resulting mixture. The vessel was installed in a planetary mill. The treatment of $\mathrm{HA} \mathrm{Ca} 10\left(\mathrm{PO}_{4}\right)_{6}(\mathrm{OH})_{2}$ powder in water solution of oxalic acid $\mathrm{H}_{2} \mathrm{C}_{2} \mathrm{O}_{4}(1 \mathrm{M})$ was conducted for $15 \mathrm{~min}$ in a planetary mill (Fritch Pulverisette, Germany) at rotation speed of $500 \mathrm{rpm}$. Then the resulting suspension was placed into porcelain cup and dried in air for a week until the water completely evaporated.

Pre-ceramic powder compacts in the form of discs with a diameter of $12 \mathrm{~mm}$ and a height of 2-3 mm were made from prepared powder mixture using a manual press (Carver Laboratory Press model C, USA) at $100 \mathrm{MPa}$ using a steel mold. Then the samples were fired in a furnace at $500{ }^{\circ} \mathrm{C}, 1000{ }^{\circ} \mathrm{C}, 1100{ }^{\circ} \mathrm{C}$ and $1200{ }^{\circ} \mathrm{C}$ with exposure at the specified temperatures for 2 hours (the heating rate of the furnace was $5^{\circ} \mathrm{C} / \mathrm{min}$ ). The mass, linear dimensions of the samples were measured before and after firing. Then linear shrinkage and density of samples were calculated. Prepared powder mixture was additionally heat treated at $200{ }^{\circ} \mathrm{C}$ with exposure at this temperature for 30 minutes (the heating rate of the furnace was $5^{\circ} \mathrm{C} / \mathrm{min}$ ) for better understanding of processes of transformation of phase composition of powder system under heating.

The phase composition of the powder mixture after treatment in a planetary mill and after heat treatment at $200{ }^{\circ} \mathrm{C}$ as well as ceramic samples after firing was determined by X-ray powder diffraction (XRD) analysis on a Rigaku D/Max-2500 diffractometer (Japan) with a rotating anode, using $\mathrm{Cu}-\mathrm{Ka}$ radiation (average wavelength $\lambda=1.54183 \AA$ ), accelerating voltage $50 \mathrm{kV}$, tube current $250 \mathrm{~mA}$, angle interval $2 \Theta$ : from $2^{\circ}$ to $70^{\circ}$, step $2 \Theta$ - 
$0.02^{\circ}$, speed $\left.4^{\circ} / \mathrm{min}\right)$. Phase analysis was performed using ICDD PDF2 database $\left[{ }^{18}\right]$ and Match!3 software (https://www.crystalimpact.com/).

Prepared powder mixture after drying was examined by synchronous thermal analysis (TA), which was performed on a NETZSCH STA 449 F3 Jupiter thermal analyzer (NETZSCH, Germany) at a heating rate of $10^{\circ} \mathrm{C} / \mathrm{min}$. The mass of the sample was at least $10 \mathrm{mg}$. The composition of the gas phase formed during the heating of powder mixture was studied using a quadrupole mass spectrometer QMS 403 Quadro (NETZSCH, Germany) combined with a thermal analyzer NETZSCH STA 449 F3 Jupiter. Mass spectra (MS) were recorded for the mass numbers $18\left(\mathrm{H}_{2} \mathrm{O}\right) ; 44\left(\mathrm{CO}_{2}\right)$.

Powder mixture after treatment in a planetary mill and ceramics after firing were examined by scanning electron microscopy (SEM) on LEO SUPRA 50VP electron microscope (Carl Zeiss, Germany; auto-emission source). This investigation was carried out at an accelerating voltage of 3-20 kV in secondary electrons (SE2 detector). The surface of the samples was coated with a layer of chromium (up to $10 \mathrm{~nm}$ ).

\section{Results and Discussion}

According to the XRD data (Figure 1), the phase composition of powder mixture obtained as a result of the interaction of $\mathrm{HA} \mathrm{Ca} 10\left(\mathrm{PO}_{4}\right)_{6}(\mathrm{OH})_{2}$ powder with a $1 \mathrm{M}$ water solution of oxalic acid $\mathrm{H}_{2} \mathrm{C}_{2} \mathrm{O}_{4}$ under mechanical activation condition and drying in air for a week consisted of brushite (calcium hydrophosphate dihydrate) $\mathrm{CaHPO}_{4} \cdot 2 \mathrm{H}_{2} \mathrm{O}$ and calcium oxalate monohydrate $\mathrm{CaC}_{2} \mathrm{O}_{4} \cdot \mathrm{H}_{2} \mathrm{O}$ in form of whewellite (PDF card 20-231) and weddellite (PDF card 17-541).

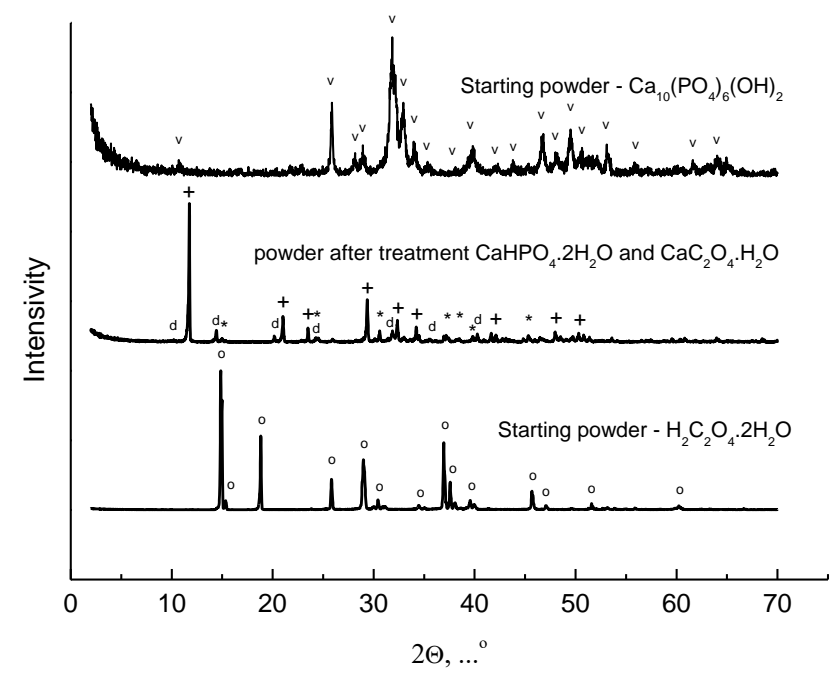

Figure 1. XRD data for starting components and resulting powder mixture: $\mathrm{v}-\mathrm{Ca} 10\left(\mathrm{PO}_{4}\right)_{6}(\mathrm{OH})_{2}(\mathrm{PDF}$ card 9-432); o - $\mathrm{H}_{2} \mathrm{C}_{2} \mathrm{O}_{4} \cdot 2 \mathrm{H}_{2} \mathrm{O}$ (PDF card 14-832); + - $\mathrm{CaHPO}_{4} \cdot 2 \mathrm{H}_{2} \mathrm{O}$ (PDF card 9-77); * - $\mathrm{CaC}_{2} \mathrm{O}_{4} \cdot \mathrm{H}_{2} \mathrm{O}$ (PDF card 20-231); d - $\mathrm{CaC}_{2} \mathrm{O}_{4} \cdot \mathrm{H}_{2} \mathrm{O}$ (PDF card 17-541).

The XRD data confirmed that reaction (1) took place during treatment in planetary mill and drying of suspension. According to Match!3 software (https://www.crystalimpact.com/) phase composition of prepared powder mixture consisted of brushite Ca$\mathrm{HPO}_{4} \cdot 2 \mathrm{H}_{2} \mathrm{O}$ (Entry number 96-231-0527, $84.1 \%$ ) $\left.{ }^{19}\right]$ and weddellite $\mathrm{CaC}_{2} \mathrm{O}_{4} \cdot 2.2 \mathrm{H}_{2} \mathrm{O}$ (Entry number 96-231-0999, 15,9\%) [20]. Additionally, the Match! Phase Analysis Report marked $30 \%$ as unidentified peak area. Phase composition of prepared powder mixture determined by using different programs are in good correlation. It should be noted that some quasi-crystalline phases not detected via XRD could form during interaction of HA Ca10 $\left(\mathrm{PO}_{4}\right)_{6}(\mathrm{OH})_{2}$ powder with water solution of oxalic acid $\mathrm{H}_{2} \mathrm{C}_{2} \mathrm{O}_{4}$.

Figure 2 shows a micrographs of a powder mixture obtained as a result of the interaction of $\mathrm{HA} \mathrm{Ca} 10\left(\mathrm{PO}_{4}\right)_{6}(\mathrm{OH})_{2}$ powder with an $1 \mathrm{M}$ water solution of oxalic acid $\mathrm{H}_{2} \mathrm{C}_{2} \mathrm{O}_{4}$ under 
conditions of mechanical activation and drying in air during 1 week. On the micrograph, one can see two kinds of particles: particles of a plate-like morphology with dimensions about 10-20 mm (Figure 2, a) and particles of isometric morphology and dimensions up to $100 \mathrm{~nm}$. The plate-like morphology is inherent to brushite $\mathrm{CaHPO}_{4} \cdot 2 \mathrm{H}_{2} \mathrm{O}$ according to scientific literature data and our experience [ $\left.{ }^{21}\right]$. So, we could assume that particles with isometric morphology and dimensions up to $100 \mathrm{~nm}$ were weddellite or whewellite (calcium oxalate monohydrate) $\mathrm{CaC}_{2} \mathrm{O}_{4} \cdot \mathrm{H}_{2} \mathrm{O}$. One can see that these isomeric particles presented in powder as aggregates with dimensions of 500-1000 nm and as individual particles on the surface of plate-like brushite $\mathrm{CaHPO}_{4} \cdot 2 \mathrm{H}_{2} \mathrm{O}$ particles.
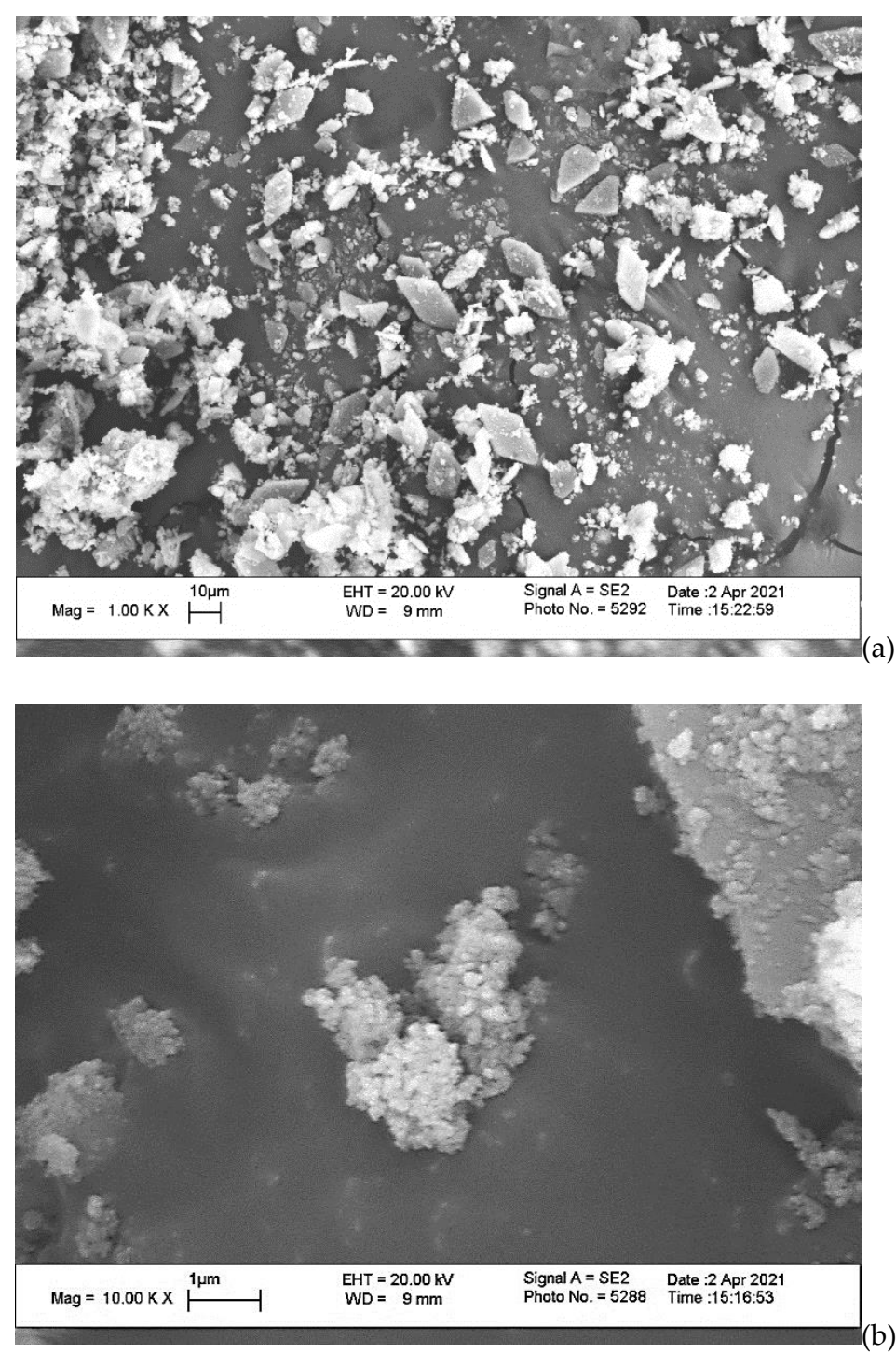

Figure 2. SEM images of the powder mixture obtained by the interaction of HA powder $\mathrm{Ca} 10\left(\mathrm{PO}_{4}\right)_{6}(\mathrm{OH})_{2}$ with a water solution of oxalic acid $\mathrm{H}_{2} \mathrm{C}_{2} \mathrm{O}_{4}$ under mechanical activation after drying in air for a week: x1000 (a) and x 10000 (b).

Figure 3 shows the data of synchronous thermal analysis: thermogravimetry (TG) and differential scanning calorimetry (DSC) curves for the studied powder mixture when heated from $40{ }^{\circ} \mathrm{C}$ to $1000^{\circ} \mathrm{C}$. Figure 4 shows the mass spectra of evolving gases with $\mathrm{m} / \mathrm{Z}$ $=18\left(\mathrm{H}_{2} \mathrm{O}\right)$ and $\mathrm{m} / \mathrm{Z}=44\left(\mathrm{CO}_{2}\right)$ resulting from the thermal decomposition of components of the powder mixture. The total mass loss of the powder mixture when heated up to 1000 ${ }^{\circ} \mathrm{C}$ was $33 \%$. It should be noted that if powder mixture consisted only from product formed according reaction (1) the total mass loss according calculation would be $42 \%$. This fact can additionally points on possible presence of non-detected by means of XRD less 
hydrated quasi-amorphous products formed during treatment of HA Ca10 $\left(\mathrm{PO}_{4}\right)_{6}(\mathrm{OH})_{2}$ powder in water solution of oxalic acid $\mathrm{H}_{2} \mathrm{C}_{2} \mathrm{O}_{4}$ in the condition of mechanical activation. There are 3 noticeable steps on the curve of mass loss. The mass loss at the first step is estimated as $14 \%\left(90-300{ }^{\circ} \mathrm{C}\right)$, at the second step - $10 \%\left(300-550{ }^{\circ} \mathrm{C}\right)$ and at the third step $-9 \%\left(550-750{ }^{\circ} \mathrm{C}\right)$.

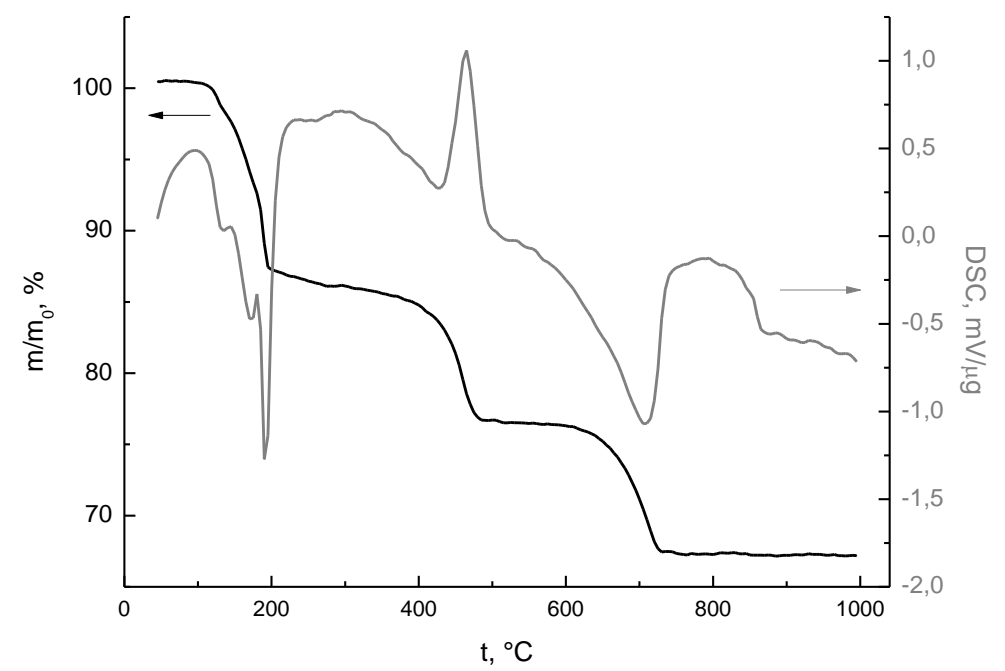

Figure 3. The results of synchronous thermal analysis (TA): thermogravimetry curves (TG, in black) and differential scanning calorimetry (DSC, in gray).

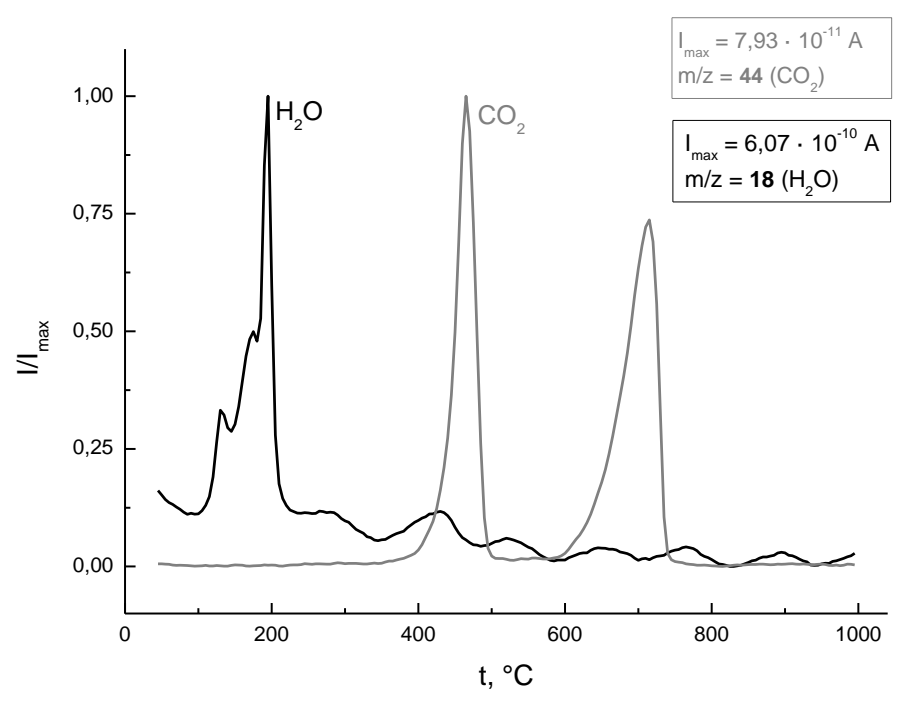

Figure 4. Mass spectra for evolving gases with $\mathrm{m} / \mathrm{Z}=18$ (in black) and $\mathrm{m} / \mathrm{Z}=44$ (in grey). Curves were normalized with respect to $\operatorname{Imax}=6.07 \cdot 10^{-10} \mathrm{~A}$ for $\mathrm{H}_{2} \mathrm{O}(\mathrm{m} / \mathrm{Z}=18)$ and to $\operatorname{Imax}=7.93 \cdot 10^{-11} \mathrm{~A}$ for $\mathrm{CO}_{2}$ $(\mathrm{m} / \mathrm{Z}=44)$.

There are 3 endo-peaks on the DSC curve in the first temperature interval $\left(130^{\circ} \mathrm{C}, 173^{\circ} \mathrm{C}\right.$, and $\left.192^{\circ} \mathrm{C}\right)$. In the mass spectrum curve for $\mathrm{m} / \mathrm{Z}=18\left(\mathrm{H}_{2} \mathrm{O}\right)$ in this range of $90-300{ }^{\circ} \mathrm{C}$ one can see 3 peaks at the same temperatures. Thermal decomposition of whewellite/weddellite $\mathrm{CaC}_{2} \mathrm{O}_{4} \cdot \mathrm{H}_{2} \mathrm{O}$ and brushite $\mathrm{CaHPO}_{4} \cdot 2 \mathrm{H}_{2} \mathrm{O}$ can take place in this range of temperatures according to reactions (2) and (3) respectively with the formation of anhydrous calcium oxalate $\mathrm{CaC}_{2} \mathrm{O}_{4}$ and monetite $\mathrm{CaHPO}_{4}$.

$$
\mathrm{CaC}_{2} \mathrm{O}_{4} \cdot \mathrm{H}_{2} \mathrm{O}=\mathrm{CaC}_{2} \mathrm{O}_{4}+\mathrm{H}_{2} \mathrm{O}
$$




$$
\mathrm{CaHPO}_{4} \cdot 2 \mathrm{H}_{2} \mathrm{O}=\mathrm{CaHPO}_{4}+2 \mathrm{H}_{2} \mathrm{O}
$$

According to scientific literature data thermal decomposition of $\mathrm{CaC}_{2} \mathrm{O}_{4} \cdot \mathrm{H}_{2} \mathrm{O}$ (reaction (2)) takes place at $167.9{ }^{\circ} \mathrm{C}\left[{ }^{22}\right]$ and thermal decomposition of brushite $\mathrm{CaHPO}_{4} \cdot 2 \mathrm{H}_{2} \mathrm{O}$ takes place at $200{ }^{\circ} \mathrm{C}$ (reaction (3)) [ ${ }^{23}$. It should be noted that simulations presence of these two hydrated salts can influence on thermal decomposition processes of each of them. Probably the mass loss at $130{ }^{\circ} \mathrm{C}$ can be explained with possible interaction of these two hydrated calcium salts. Also, this peak may reflect the process of thermal transformation of any undetected by XRD quasi-amorphous phase presence of which estimated as possible. After heat treatment at $200{ }^{\circ} \mathrm{C}$ according to XRD data (Figure 5, Table 1) the following phases were detected in the powder mixture: $\mathrm{CaHPO}_{4}, \mathrm{Ca}_{3}\left(\mathrm{PO}_{4}\right)_{2} \cdot \mathrm{xH}_{2} \mathrm{O}, \mathrm{CaC}_{2} \mathrm{O}_{4} \cdot \mathrm{H}_{2} \mathrm{O}$. The presence of $\mathrm{CaC}_{2} \mathrm{O}_{4} \cdot \mathrm{H}_{2} \mathrm{O}$ in powder mixture indicates the incompleteness of the thermal decomposition process according to reaction (2). The form of the XRD curve (Figure 5) indicates that a remarkable part of the powder mixture under investigation presents in quasi-amorphous form after heat treatment at $200{ }^{\circ} \mathrm{C}$.

The second noticeable step on the curve of mass loss is in the temperature interval of 300$550{ }^{\circ} \mathrm{C}$ (Figure 3 ). At mass spectra for $\mathrm{m} / \mathrm{Z}=44$ in this interval there is a peak $\left(465{ }^{\circ} \mathrm{C}\right)$ reflecting $\mathrm{CO}_{2}$ evolving. The thermal decomposition of anhydrous calcium oxalate $\mathrm{CaC}_{2} \mathrm{O}_{4}$ with formation of calcium carbonate $\mathrm{CaCO}_{3}$ takes place with the release of heat (DSC curve, Figure 3) according to reaction (4) [22, Chang].

$$
\mathrm{CaC}_{2} \mathrm{O}_{4}+1 / 2 \mathrm{O}_{2}=\mathrm{CaCO}_{3}+\mathrm{CO}_{2}
$$

Grey color of the samples after firing at $500{ }^{\circ} \mathrm{C}$ give us opportunity to conclude about presence of some quantity of amorphous carbon in the powder compact. In the temperature range from $400{ }^{\circ} \mathrm{C}$ to $450{ }^{\circ} \mathrm{C}$, monetite $\mathrm{CaHPO}_{4}$ undergoes dehydration with the formation of calcium diphosphate $\gamma-\mathrm{Ca}_{2} \mathrm{P}_{2} \mathrm{O}_{7}$ (reaction (5), which is confirmed by a peak (425 ${ }^{\circ} \mathrm{C}$ ) on the mass spectrum curve (Figure $4, \mathrm{~m} / \mathrm{Z}=18$ ).

$$
2 \mathrm{CaHPO}_{4}=\gamma-\mathrm{Ca}_{2} \mathrm{P}_{2} \mathrm{O}_{7}+\mathrm{H}_{2} \mathrm{O}
$$

XRD data after heat treatment at $500{ }^{\circ} \mathrm{C}$ (Figure 5, Table 1) confirm presence of calcium carbonate $\mathrm{CaCO}_{3}$ in form of calcite and $\gamma$-calcium pyrophosphate $\gamma-\mathrm{Ca}_{2} \mathrm{P}_{2} \mathrm{O}_{7}$ in the phase composition of samples. Simultaneous presence at powder system of calcium carbonate $\mathrm{CaCO}_{3}$ and calcium pyrophosphate $\mathrm{Ca}_{2} \mathrm{P}_{2} \mathrm{O}_{7}$ makes it possible the formation of tricalcium phosphate $\mathrm{Ca}_{3}\left(\mathrm{PO}_{4}\right)_{2}$ or hydroxyapatite $\mathrm{Ca}_{10}\left(\mathrm{PO}_{4}\right)_{6}(\mathrm{OH})_{2}$ according to reactions (6) and (7). Tricalcium phosphate $\mathrm{Ca}_{3}\left(\mathrm{PO}_{4}\right)_{2}$ can form due to thermal decomposition of hydrated tricalcium phosphate $\mathrm{Ca}_{3}\left(\mathrm{PO}_{4}\right)_{2} \mathrm{xH}_{2} \mathrm{O}$ (analog of Ca-deficient $\left.\mathrm{HA}-\mathrm{Ca} 9\left(\mathrm{HPO}_{4}\right)\left(\mathrm{PO}_{4}\right)_{5}(\mathrm{OH})\right)$ (reaction (8) and (9). Moreover, hydroxyapatite $\mathrm{Ca}_{10}\left(\mathrm{PO}_{4}\right)_{6}(\mathrm{OH})_{2}$ can form from tricalcium phosphate $\mathrm{Ca}_{3}\left(\mathrm{PO}_{4}\right)_{2}$ and calcium carbonate $\mathrm{CaCO}_{3}$ according reaction (10).

$$
\begin{gathered}
\mathrm{CaCO}_{3}+\mathrm{Ca}_{2} \mathrm{P}_{2} \mathrm{O}_{7}=\mathrm{Ca}_{3}\left(\mathrm{PO}_{4}\right)_{2}+\mathrm{CO}_{2} \\
4 \mathrm{CaCO}_{3}+3 \mathrm{Ca}_{2} \mathrm{P}_{2} \mathrm{O}_{7}+\mathrm{H}_{2} \mathrm{O}=\mathrm{Ca} 10\left(\mathrm{PO}_{4}\right)_{6}(\mathrm{OH})_{2}+4 \mathrm{CO}_{2} \\
\mathrm{Ca}_{3}\left(\mathrm{PO}_{4}\right)_{2} \times \mathrm{H}_{2} \mathrm{O}=\mathrm{Ca}_{3}\left(\mathrm{PO}_{4}\right)_{2}+\mathrm{xH}_{2} \mathrm{O} \\
\mathrm{Ca}_{9}\left(\mathrm{HPO}_{4}\right)\left(\mathrm{PO}_{4}\right)_{5}(\mathrm{OH})=3 \mathrm{Ca}_{3}\left(\mathrm{PO}_{4}\right)_{2}+\mathrm{H}_{2} \mathrm{O} \\
3 \mathrm{Ca}_{3}\left(\mathrm{PO}_{4}\right)_{2}+\mathrm{CaCO}_{3}+\mathrm{H}_{2} \mathrm{O}=\mathrm{Ca}_{10}\left(\mathrm{PO}_{4}\right)_{6}(\mathrm{OH})_{2}+\mathrm{CO}_{2}
\end{gathered}
$$

These reactions (6), (7) and (10) can explain the $\mathrm{CO}_{2}$ evolving (peak at $715^{\circ} \mathrm{C}$, Figure 4 ) in the third noticeable step at mass loss curve in the interval 550-750 ${ }^{\circ} \mathrm{C}$ (Figure 3 ). As one 
can see no mass changes were detected during heating in the interval $750-1000{ }^{\circ} \mathrm{C}$ in the TG curve.

Figure 5 shows the XRD data of powder mixture after heat treatment at $200{ }^{\circ} \mathrm{C}$ and ceramic samples based on powder mixture prepared from powder of $\mathrm{HACa} \mathrm{Ca}_{10}\left(\mathrm{PO}_{4}\right)_{6}(\mathrm{OH})_{2}$ and oxalic acid dihydrate $\mathrm{H}_{2} \mathrm{C}_{2} \mathrm{O}_{4} \cdot 2 \mathrm{H}_{2} \mathrm{O}$ after firing at $500{ }^{\circ} \mathrm{C}, 1000{ }^{\circ} \mathrm{C}, 1100{ }^{\circ} \mathrm{C}$ and $1200{ }^{\circ} \mathrm{C}$. Table 1 briefly summarizes phase transformations in powder system under investigation from starting powder mixture $\left(\mathrm{CaHPO}_{4} \cdot 2 \mathrm{H}_{2} \mathrm{O}, \mathrm{CaC}_{2} \mathrm{O}_{4} \cdot \mathrm{H}_{2} \mathrm{O}\right.$, non-identified phase quasi-amorphous phase) to final monophase $\mathrm{HA}\left(\mathrm{Ca}_{10}\left(\mathrm{PO}_{4}\right)_{6}(\mathrm{OH})_{2}\right)$ ceramics. Phase composition of ceramics after firing at $1000{ }^{\circ} \mathrm{C}$ included $\mathrm{HA}\left(\mathrm{Ca} 10\left(\mathrm{PO}_{4}\right)_{6}(\mathrm{OH})_{2}\right), \beta$-tricalcium phosphate $\beta$ $\mathrm{Ca}_{3}\left(\mathrm{PO}_{4}\right)_{2}$, and small quantity of calcite $\mathrm{CaCO}_{3}$. The presence of $\beta$-tricalcium phosphate $\beta$ $\mathrm{Ca}\left(\mathrm{PO}_{4}\right)_{2}$ after firing at $1000{ }^{\circ} \mathrm{C}$ can be explained with possibility of reaction (6) in the 550$770{ }^{\circ} \mathrm{C}$ interval and reaction (9) and (10) describing transformation of hydrated tricalcium phosphate (as it described in PDF card 18-303) or Ca-deficient hydroxyapatite $\mathrm{Ca} 9\left(\mathrm{HPO}_{4}\right)\left(\mathrm{PO}_{4}\right)_{5}(\mathrm{OH})$ to the $\beta$-tricalcium phosphate $\beta-\mathrm{Ca}_{3}\left(\mathrm{PO}_{4}\right)_{2}$ which is possible in the 650-800 ${ }^{\circ} \mathrm{C}$ interval $\left[{ }^{24},{ }^{25}\right]$.

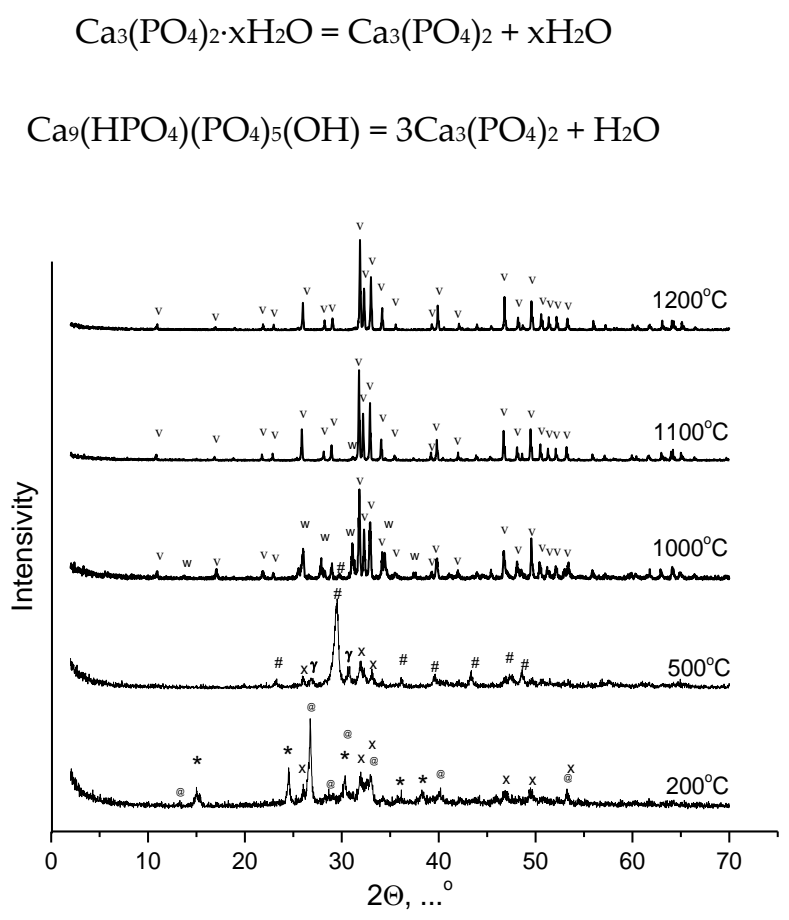

Figure 5. XRD data for powder mixture $\left(200{ }^{\circ} \mathrm{C}\right)$ and ceramic samples $\left(500{ }^{\circ} \mathrm{C}, 1000^{\circ} \mathrm{C}, 1100^{\circ} \mathrm{C}\right.$ and $1200{ }^{\circ} \mathrm{C}$ ) after firing: v - Ca10 $\left(\mathrm{PO}_{4}\right)_{6}(\mathrm{OH})_{2}\left(\mathrm{PDF}\right.$ card 9-432); $\mathrm{w}-\beta-\mathrm{Ca}_{3}\left(\mathrm{PO}_{4}\right)_{2}(\mathrm{PDF}$ card 9-169); "\#" $\mathrm{CaCO}_{3}$ (PDF card 5-586), * - $\mathrm{CaC}_{2} \mathrm{O}_{4} \cdot \mathrm{H}_{2} \mathrm{O}$ (PDF card 20-231); @ - $\mathrm{CaHPO}_{4}$ (PDF card 9-80); $\mathrm{x}$ $\mathrm{Ca} 3\left(\mathrm{PO}_{4}\right)_{2} \cdot \mathrm{xH}_{2} \mathrm{O}$ (PDF card 18-303); $\gamma-\gamma-\mathrm{Ca}_{2} \mathrm{P}_{2} \mathrm{O}_{7}$ (PDF card 17-499).

Phase composition of ceramics after firing at $1100{ }^{\circ} \mathrm{C}$ included $\mathrm{HA}\left(\mathrm{Ca} 10\left(\mathrm{PO}_{4}\right)_{6}(\mathrm{OH})_{2}\right)$ and small quantity of $\beta$-tricalcium phosphate $\beta$ - $\mathrm{Ca}_{3}\left(\mathrm{PO}_{4}\right)_{2}$. And finally phase composition of ceramics after firing at $1200{ }^{\circ} \mathrm{C}$ included the only phase - $\mathrm{HA}\left(\mathrm{Ca} 10\left(\mathrm{PO}_{4}\right)_{6}(\mathrm{OH})_{2}\right)$.

Table 1. Phase composition of powder mixtures and ceramic samples.

\begin{tabular}{|c|c|c|c|c|c|}
\hline After mill & $200{ }^{\circ} \mathrm{C}$ & $500{ }^{\circ} \mathrm{C}$ & $1000^{\circ} \mathrm{C}$ & $1100^{\circ} \mathrm{C}$ & $1200^{\circ} \mathrm{C}$ \\
\hline $\begin{array}{l}\mathrm{CaHPO}_{4} \cdot 2 \mathrm{H}_{2} \mathrm{O} \\
\text { non-identified phase } \\
\mathrm{CaC}_{2} \mathrm{O}_{4} \cdot \mathrm{H}_{2} \mathrm{O}\end{array}$ & $\begin{array}{l}\mathrm{CaHPO}_{4} \\
\mathrm{Ca}_{3}\left(\mathrm{PO}_{4}\right)_{2} \cdot \mathrm{xH}_{2} \mathrm{O} \\
\mathrm{CaC}_{2} \mathrm{O}_{4} \cdot \mathrm{H}_{2} \mathrm{O}\end{array}$ & $\begin{array}{l}\gamma-\mathrm{Ca}_{2} \mathrm{P}_{2} \mathrm{O}_{7} \\
\mathrm{Ca}_{3}\left(\mathrm{PO}_{4}\right)_{2} \times \mathrm{H}_{2} \mathrm{O} \\
\mathrm{CaCO}_{3}\end{array}$ & $\begin{array}{l}\mathrm{Ca}_{10}\left(\mathrm{PO}_{4}\right)_{6}(\mathrm{OH})_{2} \\
\beta-\mathrm{Ca}_{3}\left(\mathrm{PO}_{4}\right)_{2} \\
\mathrm{CaCO}_{3} *\end{array}$ & $\begin{array}{l}\mathrm{Ca} 10_{\left(\mathrm{PO}_{4}\right)_{6}(\mathrm{OH})_{2}} \\
\beta-\mathrm{Ca}_{3}\left(\mathrm{PO}_{4}\right)_{2} \text { * }\end{array}$ & $\mathrm{Ca}_{10}\left(\mathrm{PO}_{4}\right)_{6}(\mathrm{OH})_{2}$ \\
\hline
\end{tabular}

* - small quantity 
XRD data of samples after heat treatment at different temperatures shows that formation of single-phase HA-ceramics from multi-components homogenized powder mixture took place as complicated sequence of different heterogeneous reactions, including thermal decomposition reactions and solid-state reactions. As it is knowing from the scientific literature heterophase reactions can take place during firing and accompany sintering process of HA-ceramics $\left[{ }^{26},{ }^{27}\right]$. Investigation presented in this article emphasizes the importance of the preset $\mathrm{Ca} / \mathrm{P}=1,67$ molar ratio in starting powder mixture when preparing ceramics based on HA. Presetting of $\mathrm{Ca} / \mathrm{P}=1,67$ in starting powder mixture in this work was guaranteed both by high quality of HA powder used and by preparation of powder mixture in via acid-base reaction in mechanical activation condition. This method excludes changes in preset $\mathrm{Ca} / \mathrm{P}$ molar ratio due to difference in solubility of starting components or influence of $\mathrm{pH}$ on preferability of formation of one or other phases as it would possible in case of precipitation of calcium phosphate powders from solutions.

Micrograph of the surface of the ceramic sample based on powder mixture including brushite (calcium hydrophosphate dihydrate) $\mathrm{CaHPO}_{4} \cdot 2 \mathrm{H}_{2} \mathrm{O}$ and calcium oxalate monohydrate $\mathrm{CaC}_{2} \mathrm{O}_{4} \cdot \mathrm{H}_{2} \mathrm{O}$ in form of whewellite and weddellite after firing at $1200{ }^{\circ} \mathrm{C}$ is presented at Figure 6. Microstructure of ceramic sample fired at $1200{ }^{\circ} \mathrm{C}$ consisted of polycrystalline plate-like particles with dimensions 5-15 $\mu \mathrm{m}$, arched groups of particles 0,5-2 $\mu \mathrm{m}$, and two kinds of pores with dimensions about 10 and 1-2 $\mu \mathrm{m}$. Obviously microstructure of HA-ceramics inherits microstructure of starting powder mixture. It can be assumed that formation of phase of HA was realized both on the surface of nano sized particles of calcium oxalate/calcium carbonate and on the surface of micro sized plate-like particles of brushite/monetite/calcium pyrophosphate.

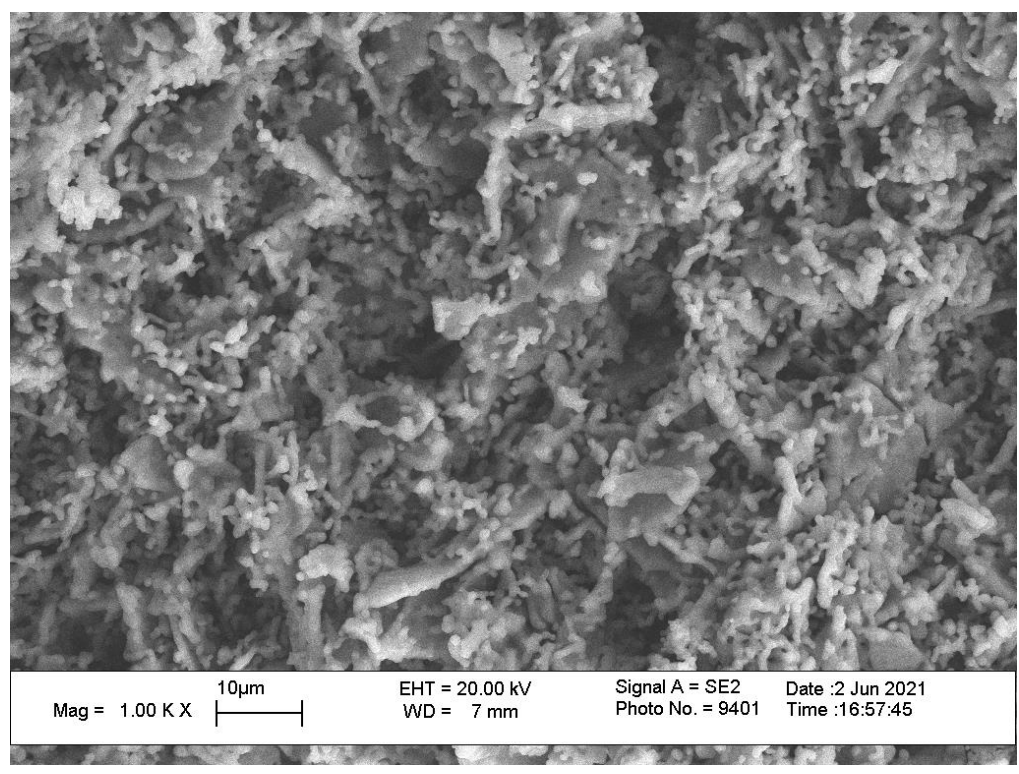

Figure 6. Micrograph of the surface of the ceramic sample based on powder mixture including brushite (calcium hydrophosphate dihydrate) $\mathrm{CaHPO}_{4} \cdot 2 \mathrm{H}_{2} \mathrm{O}$, calcium oxalate monohydrate $\mathrm{CaC}_{2} \mathrm{O}_{4} \cdot \mathrm{H}_{2} \mathrm{O}$ in form of whewellite and weddellite and non-identified phase after firing at $1200{ }^{\circ} \mathrm{C}$. 

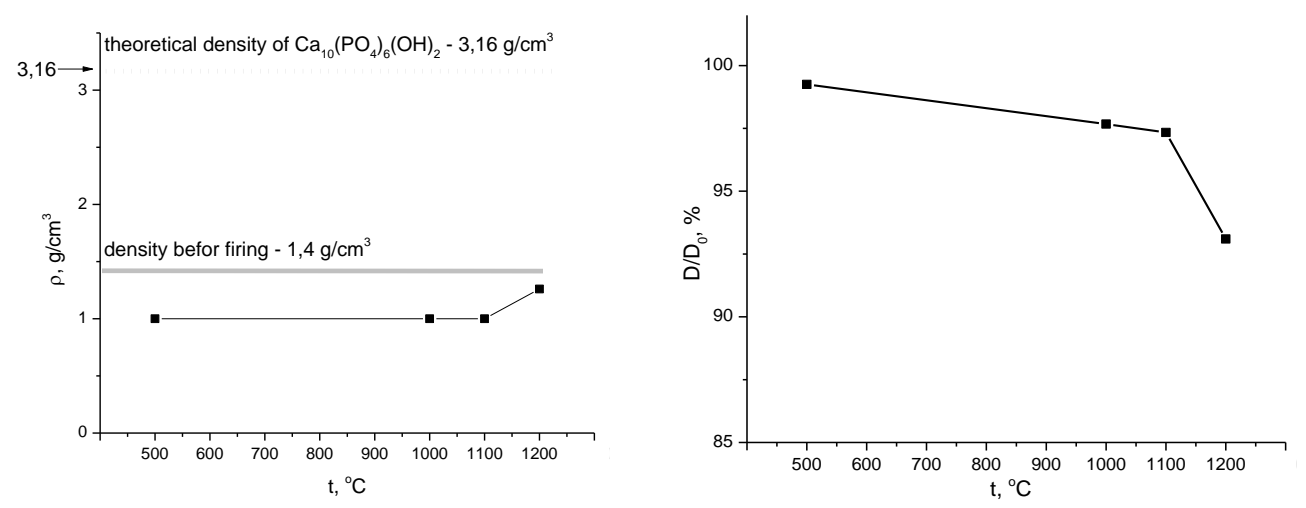

Figure 7. Apparent density $\left(\mathrm{g} / \mathrm{cm}^{3}\right)$ and relative diameter $\left(\mathrm{D} / \mathrm{D}_{0}, \%\right)$ of ceramic samples base on powder mixture $\left(\mathrm{CaHPO}_{4} \cdot 2 \mathrm{H}_{2} \mathrm{O}, \mathrm{CaC}_{2} \mathrm{O}_{4} \cdot \mathrm{H}_{2} \mathrm{O}\right.$, non-identified quasi-amorphous phase) after firing at different temperatures.

Apparent density $\left(\mathrm{g} / \mathrm{cm}^{3}\right)$ and relative diameter $\left(\mathrm{D} / \mathrm{D}_{0}, \%\right)$ of ceramic samples after firing at different temperatures are presented at Figure 7. Linear shrinkage increased very slowly from $1 \%$ at $500 \mathrm{oC}$ up to $2,7 \%$ at $1100{ }^{\circ} \mathrm{C}$ and reach the maximum $7 \%$ at $1200{ }^{\circ} \mathrm{C}$. Liner shrinkage of HA-ceramics based on uniform synthetic HA powders consisted of isometric particles could reach about $20 \%$ [ $\left.{ }^{28}\right]$ or even more than $20 \%$ [ $\left.{ }^{29}\right]$. Ceramic samples prepared from powder mixture $\left(\mathrm{CaHPO}_{4} \cdot 2 \mathrm{H}_{2} \mathrm{O}, \mathrm{CaC}_{2} \mathrm{O}_{4} \cdot \mathrm{H}_{2} \mathrm{O}\right.$, non-identified quasi-amorphous phase) had the maximum density $1.25 \mathrm{~g} / \mathrm{cm}^{3}(\sim 40 \%$ relatively theoretical density of HA) after firing at $1200^{\circ} \mathrm{C}$. So, microstructure of HA-ceramics (Figure 6), data of apparent density and relative diameter after firing (Figure 7) confirm possibility to created microporosity via using of powder mixture with plate-like particle restraining shrinkage during sintering.

\section{Conclusions}

Powder mixture with given molar ratio $\mathrm{Ca} / \mathrm{P}=1.67$ consisting of plate-like particles of brushite (calcium hydrophosphate dihydrate) $\mathrm{CaHPO}_{4} \cdot 2 \mathrm{H}_{2} \mathrm{O}$; nanosized isometric particles of calcium oxalate monohydrate $\mathrm{CaC}_{2} \mathrm{O}_{4} \cdot \mathrm{H}_{2} \mathrm{O}$ in form of whewellite and weddellite; and some quantity of non-identified quasi-amorphous phase was obtained as a result of the interaction of HA powder $\mathrm{Ca}_{10}\left(\mathrm{PO}_{4}\right)_{6}(\mathrm{OH})_{2}$ with an aqueous solution of oxalic acid $\mathrm{H}_{2} \mathrm{C}_{2} \mathrm{O}_{4}$ at a molar ratio of $\mathrm{Ca}_{10}\left(\mathrm{PO}_{4}\right)_{6}(\mathrm{OH})_{2} / \mathrm{H}_{2} \mathrm{C}_{2} \mathrm{O}_{4}=1: 4$ under mechanical activation conditions. This powder was used for creation of microporous monophase HA $\mathrm{Ca} 10\left(\mathrm{PO}_{4}\right)_{6}(\mathrm{OH})_{2}$ ceramics. Components of prepared powder mixture with preset $\mathrm{Ca} / \mathrm{P}=1.67$ molar ratio take part both in sequences of thermal transformations such as dehydration and decomposition and then in sequences of hetero phase reactions leading to final and target phase composition of ceramics presented by HA Ca10 $\left(\mathrm{PO}_{4}\right)_{6}(\mathrm{OH})_{2}$. It was shown that plate-like particles presented in the powder used for ceramic creation can restrain sintering process and provide the formation of microporosity of HA $\mathrm{Ca} 10\left(\mathrm{PO}_{4}\right)_{6}(\mathrm{OH})_{2}$. ceramics.

Author Contributions: Conceptualization, T.S. (Tatiana Safronova); methodology, T.S. (Tatiana Safronova); investigation, S.C., T.S. (Tatiana Shatalova), Y.F., T.S. (Tatiana Safronova); writing - original draft preparation, S.C., T.S. (Tatiana Safronova); writing - review and editing, S.C., T.S. (Tatiana Safronova); visualization, S.C., T.S. (Tatiana Shatalova), Y.F., T.S. (Tatiana Safronova); supervision, T.S. (Tatiana Safronova); project administration, T.S. (Tatiana Safronova); funding acquisition, T.S. (Tatiana Safronova). All authors have read and agreed to the published version of the manuscript.

Funding: This research was funded by Russian Foundation for Basic Research, grant number 18-2911079.

Acknowledgments: The research was carried out using the equipment of MSU Shared Research Equipment Center "Technologies for obtaining new nanostructured materials and their complex 
study" and purchased by MSU in the frame of the Equipment Renovation Program (National Project "Science") and in the frame of the MSU Program of Development.

Conflicts of Interest: The authors declare no conflict of interest.

\section{References}

1 Huang, J.; Best S.M. Ceramic biomaterials for tissue engineering //In Tissue engineering using ceramics and polymers, 3nd ed.; Boccaccini,A.R.; Ma, P.X.; Liverani, L. Eds.; Woodhead Publishing: United Kingdom, 2022; Chapter 1, pp. 3-40. ISBN 9780128205082, https://doi.org/10.1016/B978-0-12-820508-2.00007-6

2 Matveichuk, I.V.; Rozanov, V.V.; and Litvinov, Yu.Yu. Biophysical properties of bone tissue for biomedical applications, Al'manakh Klinich. Med., 2016, 44 (2), 193-202. https://doi.org/10.18786/2072-0505-2016-44-2-193-202

3 Quelch, K.J.; Melick, R.A.; Bingham, P.J.; Mercuri, S. M. Chemical composition of human bone. Arch. Oral Biol. 1983, 28 (8), 665-674. https://doi.org/10.1016/0003-9969(83)90100-0

4 Simske, S.J.; Ayers, R.A.; Bateman, T.A. Porous materials for bone engineering. Mater. Sci. Forum., 1997, $250,151-182$. https://doi.org/10.4028/www.scientific.net/MSF.250.151

5 Yoshikawa, H.; Myoui, A. Bone tissue engineering with porous hydroxyapatite ceramics. J. Artif. Organs 2005, 8, 131-136. https://doi.org/10.1007/s10047-005-0292-1

${ }^{6}$ Jones, J.R.; Lee, P.D.; Hench, L.L. Hierarchical porous materials for tissue engineering. Philos. Trans. R. Soc. A Math. Phys. Eng. Sci., 2006, 364(1838), 263-281. https://doi.org/10.1098/rsta.2005.1689

7 DileepKumar, V.G.; Sridhar, M. S.; Aramwit, P.; Krut'ko, V. K.; Musskaya, O. N.; Glazov, I. E.; Reddy, N. A review on the synthesis and properties of hydroxyapatite for biomedical applications. J. Biomater. Sci. Polym. Ed. 2022, 33 (2), $229-261$.

8 Rial, R.; González-Durruthy, M.; Liu, Z.; Ruso, J.M. Advanced materials based on nanosized hydroxyapatite. Molecules. 2021, 26(11), 3190. https://doi.org/10.3390/molecules26113190

9 Safronova, T.V.; Putlyaev, V.I. Powder systems for calcium phosphate ceramics. Inorg. Mater. 2017,53 (1), 17-26. https://doi.org/10.1134/S0020168516130057

10 Safronova, T.V.; Putlyaev, V.I.; Shekhirev, M.A.; Kuznetsov, A.V. Disperse systems in calcium hydroxyapatite ceramics technology. Glas. Ceram. 2007, 64, 22-26. https://doi.org/10.1007/s10717-007-0006-7

11 Layrolle, P.; Ito, A.; Tateishi, T. Sol-gel synthesis of amorphous calcium phosphate and sintering into microporous hydroxyapatite bioceramics. J. Am. Ceram. Soc. 1998, 81 (6), 1421-1428. https://doi.org/10.1111/j.1151-2916.1998.tb02499.x

12 Studart, A.R.; Gonzenbach, U.T.; Tervoort, E.; Gauckler, L.J. Processing routes to macroporous ceramics: a review. 2006. J. Am. Ceram. Soc., 89(6), 1771-1789. https://doi.org/10.1111/j.1551-2916.2006.01044.x

13 Iwamoto, T.; Hieda, Y.; Kogai, Y. Effects of molecular weight on macropore sizes and characterization of porous hydroxyapatite ceramics fabricated using polyethylene glycol: mechanisms to generate macropores and tune their sizes. Mater. Today Chem. 2021, 20, 100421. https://doi.org/10.1016/j.mtchem.2021.100421

14 Seesala, V.S.; Rajasekaran, R.; Dutta, A.; Vaidya, P.V.; Dhara, S. Dense-porous multilayer ceramics by green shaping and salt leaching. Open Ceram., 2021, 5, 100084. https://doi.org/10.1016/j.oceram.2021.100084

15 Neeraj, V.S.; Wilson, P.; Vijayan, S.; Prabhakaran, K. Porous ceramics with a duplex pore structure by compression molding of alumina-NaCl paste in molten sucrose. Ceram. Int., 2017, 43 (16), 14107-14113. https://doi.org/10.1016/j.ceramint.2017.07.149

16 Barinov S.M. Calcium phosphate-based ceramic and composite materials for medicine. Russ Chem Rev. 2010, 79(1) 13-29. https://doi.org/10.1070/RC2010v079n01ABEH004098

17 Beletskii B.I.; Shumskii V.I.; Nikitin A.A.; Vlasova E.B. Biocomposite calcium-phosphate materials used in osteoplastic surgery. Glas Ceram. 2000, 57 (9-10), 322-325. https://doi.org/10.1023/A:1007182118339

18 ICDD (2010). PDF-4+ 2010 (Database), Ed. by Dr. Soorya Kabekkodu (International Centre for Diffraction Data, Newtown Square, PA, USA, 2010). http://www.icdd.com/products/pdf2.htm 
19 Beevers C.A. The crystal structure of dicalcium phosphate dihydrate, $\mathrm{CaHPO}_{4} .2 \mathrm{H}_{2} \mathrm{O}$. Acta Crystallogr. 1958,11 (4), $273-277$. https://doi.org/10.1107/S0365110X58000670

20 Sterling C. Crystal structure analysis of weddellite, $\mathrm{CaC}_{2} \mathrm{O}_{4} \cdot(2+\mathrm{x}) \mathrm{H}_{2} \mathrm{O}$. Acta Crystallogr. 1965,18 (5), 917-921. https://doi.org/10.1107/S0365110X65002219

${ }^{21}$ Safronova, T.V.; Shatalova, T.B.; Tikhonova, S.A.; Filippov, Ya.Yu.; Krut’ko, V.K.; Musskaya, O.N.; Kononenko, N.E. Synthesis of Calcium Pyrophosphate Powders from Phosphoric Acid and Calcium Carbonate. Inorg. Mater. Appl. Res. 2021, 12, 986-992. https://doi.org/10.1134/S2075113321040353

${ }_{22}$ Chang, H.; Huang, P. J. Thermal Decomposition of $\mathrm{CaC}_{2} \mathrm{O}_{4} \cdot \mathrm{H}_{2} \mathrm{O}$ Studied by Thermo-Raman Spectroscopy with TGA/DTA. Anal. Chem. 1997, 69 (8), 1485-1491. https://doi.org/10.1021/ac9608811

${ }_{23}$ Dosen, A.; Giese, R.F. Thermal decomposition of brushite, $\mathrm{CaHPO}_{4} \cdot 2 \mathrm{H}_{2} \mathrm{O}$ to monetite $\mathrm{CaHPO}_{4}$ and the formation of an amorphous phase. Am. Mineral. 2011, 96, 368-373. https://doi.org/10.2138/am.2011.3544

24 Safronova, T.V.; Putlyaev, V.I.; Avramenko, O.A.; Shekhirev, M.A.; Veresov, A.G. Ca-deficient hydroxyapatite powder for producing tricalcium phosphate based ceramics. Glas. Ceram. 2011. 68, 28-32. http://dx.doi.org/10.1007/s10717-011-9315-y

25 Safronova, T.; Putlayev, V.; Filippov, Y.; Shatalova T.; Karpushkin E.; Larionov D.; Kazakova, G.; Shakhtarin, Y. Calcium phosphate powder synthesized from calcium acetate and ammonium hydrophosphate for bioceramics application. Ceramics. 2018, 1(2), 375-392. https://doi.org/10.3390/ceramics1020030

26 Champion, E. Sintering of calcium phosphate bioceramics. Acta biomater. 2013, 9(4), 5855-5875. https://doi.org/10.1016/j.actbio.2012.11.029

27 Mitsionis A.I.; Vaimakis T.C.; Trapalis C.C. The effect of citric acid on the sintering of calcium phosphate bioceramics. Ceram Int. 2010, 36(2), 623-634. https://doi.org/10.1016/j.ceramint.2009.09.034

28 Safronova, T.V.; Shekhirev, M.A.; Putlyaev, V.I.; Tret'yakov, Y.D. Hydroxyapatite-based ceramic materials prepared using solutions of different concentrations. Inorg. Mater. 2007. 43, 901-909. https://doi.org/10.1134/S0020168507080158

${ }^{29}$ Raynaud, S.; Champion, E.; Bernache-Assollant, D. Calcium phosphate apatites with variable Ca/P atomic ratio II. Calcination and sintering. Biomaterials. 2002. 23 (4), 1073-1080. https://doi.org/10.1016/S0142-9612(01)00219-8 